\title{
“Just one animal among many?" Existential phenomenology, ethics, and stem cell research
}

\author{
Norman K. Swazo
}

Published online: 4 June 2010

(C) The Author(s) 2010. This article is published with open access at Springerlink.com

\begin{abstract}
Stem cell research and associated or derivative biotechnologies are proceeding at a pace that has left bioethics behind as a discipline that is more or less reactionary to their developments. Further, much of the available ethical deliberation remains determined by the conceptual framework of late modern metaphysics and the correlative ethical theories of utilitarianism and deontology. Lacking, to any meaningful extent, is a sustained engagement with ontological and epistemological critiques, such as with "postmodern" thinking like that of Heidegger's existential phenomenology. Some basic "Heideggerian" conceptual strategies are reviewed here as a way of remedying this deficiency and adding to ethical deliberation about current stem cell research practices.
\end{abstract}

Keywords Stem cell research $\cdot$ Phenomenology $\cdot$ Ethics $\cdot$ Heidegger

...one may be an excellent scientist without having the least idea of what one is really doing. Alexandre Koyré

\section{Beyond modern dichotomies}

Anyone examining the contemporary bioethics literature is faced with a moral framework of debate that, for the most part, appeals to the authority of either utilitarian or deontological ethical theory [1-13]. A multi-day seminar on the science, ethics, and policy of stem cell research in 2009 showed the limitations of a theoretical ethical discussion and conceptualization that is framed by a troublesome dichotomy of "pre-Enlightenment" (read here "religious") and "Enlightenment" (read here

\footnotetext{
N. K. Swazo $(\bowtie)$

College of Science and General Studies, Alfaisal University, P.O. Box 50927, Riyadh 11533,

Saudi Arabia

e-mail: nswazo@alfaisal.edu
} 
"utilitarian" and "deontological" theory) thought. ${ }^{1}$ Lost, conspicuously, is any critical engagement with the ontological and epistemological bases of these ethical theories as expressed in late modern (eighteenth to nineteenth centuries) British empiricism (J. S. Mill) and continental rationalism (I. Kant). Lost, therefore, is any meaningful appreciation of foundational problems of late modern metaphysics (as "first philosophy," prote philosophia) and how these problems have influenced the construction of moral theory (qua practical philosophy or praxis) in the modern period of philosophical reflection. In short, much of contemporary bioethics literature has yet to advance beyond the theoretical influence of late modern philosophy.

When contrasted with ongoing developments in scientific and technological research, such as in stem cell biology, and the strident pursuit of potential advances in medical therapy, the failures of biomedical ethics are staggering. The moral implications of stem cell research are especially confounding. For example:

- The moral status of pre-implantation human embryos viewed through utilitarian reasoning is not without its problematique. As Evert van Leeuwen says, “...the debate will concentrate itself on issues of possible risk, success, and so on. Utilitarian reasoning, in which the possible happiness of the many takes precedence over the luck of an individual, is combined with questions concerning the conditions in which the goal justifies the means" [14]. Yet, it is quite questionable whether the ends ever justify the means when both means and ends, as in stem cell research, are causally indeterminate and variable in efficacy.

- Similarly, viewed deontologically, "embryonic stem cell research poses a moral problem, as it brings into tension two fundamental moral principles that we highly value: the duty to prevent or alleviate suffering, and the duty to respect the value of human life. The harvesting of human embryonic stem cells violates this second duty as it results in the destruction of a possible human life. Both principles cannot simultaneously be respected in the case of embryonic stem cell research. The question then is which principle ought to be given precedence in this conflict situation" [15].

- Perhaps even more morally confounding is a recent report that British scientists have created human in vitro derived (IVD) sperm from human embryonic stem cells (hESCs), a process technically named "male gametogenesis" [16]. While human IVD-sperm currently are not functional in the way natural human spermatozoa are, the fact that human germ cells can now be produced is astounding because of uncertain long-term effects on the human germ-line and the fact that gametogenesis experiments in mice have proven unviable. Indeed, the fact that the United Kingdom outlaws the use of human IVD sperm for human reproduction and requires the destruction of human IVD-sperm fertilized ova within 14 days after fertilization points to a problematic technique, despite its claimed therapeutic potential for male infertility. Dr. Robert Lanza states one problem thus: "What's most concerning about this potential technology is that anyone, young or old, fertile or infertile,

\footnotetext{
${ }^{1}$ I am referring to a seminar, "At the Cutting Edge of Stem Cell Science...Ethical and Policy Issues," held in June 2009 at Harvard University, sponsored by the Harvard Stem Cell Institute and the Department of Bioethics of Case Western Reserve University School of Medicine, and specifically to presentations given by stem cell ethicist, Insoo Hyun; see [6].
} 
straight or gay, could potentially pass on their genes to a child from just a few cells. For instance, if you had a few skin cells from Albert Einstein —or perhaps even a hair follicle from the Pope or Queen Elizabeth-you could generate pluripotent stem cells. Any couple could go to an IVF clinic and have a child that is half say, Albert Einstein, or perhaps Brad Pitt or Elizabeth Taylor" [17, 18]. ${ }^{2}$

- Finally, there is the problem of cell biology's immersion in experiments involving transgenic techniques that create hybrids, cybrids, and chimeras, ${ }^{3}$ which bring to the fore what H. G. Wells in The Island of Dr. Moreau presents as the ethics and aesthetics of horror: "In the physical extremity of the monster, the human and the animal spheres overlap and the idea of an animal kingdom which is neatly organized in species is being revoked" [21]. Transgenic research now includes attempts to create transgenic primates with germline transmission (e.g., common marmoset, Rhesus macaque), albeit governmental prohibitions are currently in place on the creation of a "humanzee" ("the analogue of the mule") [2, 22-26]. As in Wells's dramatic presentation, we are left in reality not with the proposition that there is "nothing really dreadful" at all here, but rather with the onset of revulsion, repugnance, and insight into abomination. At minimum, there is a "sentiment of disapprobation" (a la David Hume) in the face of "a [seeming] strange wickedness" in the choices being made, assuming them to be truly choices and not mere happenstance. But, there is more than sentiment here, and the disapprobation manifests itself in the union of the ethical and the aesthetic (a unity of judgment) that is all the while ambiguous even as the propositions of moral philosophy are held in ambivalent tension with the empirical claims of reproductive biology. This is especially true of diverse conceptions of "species," thereby raising the question of what counts as transgressing boundaries between species ${ }^{4}$ - "transgression" here connotes both empirical description and

\footnotetext{
2 Adding to the problematic character of this research is the charge of plagiarism in a component of the published article; see Sarah Guy [19] and [18].

3 Dr. M. William Lensch (Harvard Stem Cell Institute) defines a "hybrid" as an organism that "arises from the admixture of DNA at the cellular level," such that "every cell in the resulting organism (or cell line if in vitro) contains DNA from both original, contributing genomes." A "cybrid" is defined as "a special case of hybrid wherein nuclear transfer (NT) is performed between oocytes and donor cells of different species (human nuclei into cow eggs...)," with the "resulting 'zygote' contain[ing] nuclear DNA of one species and mitochondrial DNA (mixture) of another species." A "chimera" is defined as "an organism containing two or more genetically distinct cell populations which originated from two or more zygotes," such that "embryo fusion results in a random distribution of cells from each original embryo throughout the entire body of the resulting adult animal"- "unless one cell type has a competitive advantage over the other." Given ongoing research on integration of such cells, the U.S. National Research Council and Institute of Medicine in 2005 published "Guidelines for Human Embryonic Stem Cell Research" and recommended (3.c.iii), "No animal into which hES cells have been introduced at any stage of development should be allowed to breed" [see 20].

${ }^{4}$ For additional reading on the ethics of transgenic research, see Baylis and Robert [27] and Ourednik [28]. For a pharmaceutical perspective, see GlaxoSmithKline [29]. Baylis and Robert write, "The idea of fixed or rigid breaks between species plays no role whatsoever in contemporary biology. Indeed, the fluidity of species boundaries has been revealed through the techniques of comparative genomics, warning against the interpretation of species as unique types."
} 
normative critique, as there is heightened interest in "proposals from some stem cell scientists to use non-human primates as an assay system for testing the developmental potential of human stem cells" [27].

The above examples illustrate that biomedical ethics continues to face significant challenges from extraordinarily imaginative developments in biotechnology, and any appropriation of post-metaphysical thinking (that emerged in the twentieth century) as it may apply to this domain of scientific research is clearly nowhere within the mainstream of the current conceptual framework. ${ }^{5}$

This thinking-transcendental or existential phenomenology, post-structuralism, and deconstruction-issues in a quest for a kind of deliberation that goes beyond metaphysical essentialism, beyond the troubled epistemological dichotomy of empiricism and rationalism, and beyond the theoretical ethical commitments of utilitarianism and deontology (without denying them a reasonable provisional authority). One consequence of this contemporary thought is that both bioethics and medical practice cannot but be characterized by a failure to be sufficiently reflective of their metaphysical (ontological, epistemological) determinants. As Iain Brassington remarked, "medicine, at least at first glance, relies on reductionist metaphysics," and "if this is correct, destructing the metaphysics means, at the very least, a radical alteration of what 'medicine' is all about" [1].

This is an important insight. One can move away from mere utilitarian and deontological moral commitments when one moves away from the metaphysical doctrines of Western modernity. One can consider, instead, what twentieth century existential phenomenology of the sort advanced by Martin Heidegger may contribute to moral deliberation about a whole host of moral dilemmas present in contemporary biomedical research and consequent innovations in medical practice. We can ask, more specifically, What happens to our bioethical thinking about stem cell research when one attains some critical distance from modern reductionist metaphysics?

I wish, then, not to ask a scientific question as such but, rather, to configure a meta-critique. The question here is, How might we think about the ethics of stem cell research when the critical distance is that enabled by Heidegger's postmetaphysical thinking? In pursuing this question here, albeit in preliminary form, my purpose is also to show that there is important post-metaphysical (Heideggerian) thinking already in place on the general problems of stem cell research and genetic engineering. As with the debate about advances in modern genetics in post-WWII Germany, the central issue here is "the status of the modern scientific project itself" [31].

\footnotetext{
5 Since I have mentioned Insoo Hyun specifically in relation to the Harvard stem cell seminar, I should say that I am aware of Hyun's earlier paper linking autonomy and authenticity. But he does so with reference to "values," a concept that is loaded with late modern philosophical content and which an existentialist phenomenologist such as Heidegger engages critically because of ontological and epistemological implications; see Hyun [30].
} 


\section{Heidegger and modern science: "Die Wissenschaft denkt nicht"}

It has been said that "Heidegger's philosophy of science never amounted to anything more than an element of his thought, and it certainly never became an element sturdy enough to bring analytic and continental camps into dialogue on the matter of science" [32]. ${ }^{6}$ Perhaps more discouraging, in terms of taking up Heidegger's thinking in relation to modern science, is Daniel Videla's observation that, "If the main trait of the condition of knowledge at the close of the millennium is-as Lyotard has it-that science no longer needs to take recourse to any philosophical (narrative, non-denotative) discourse to legitimate the production of knowledge, one may well be entitled to ask what role, if any, is left to an academic discipline that, having science as its object, calls itself philosophical?" [34]. Yet, when Heidegger says "Die Wissenschaft denkt nicht" ("Science does not think"), the production of scientific knowledge is centrally at issue.

The fact is that the sciences are positive sciences-i.e., they posit the objectdomain of investigation, even as they presuppose and do not directly query the ontological status of the objects they investigate. Thus, the sciences remain dependent on a prior clarification of a region of being, such as is accomplished by philosophical thought. Heidegger reminds us of this fact phenomenologically through the de(con)struction of the history of ontology, which is the project of his Being and Time. Videla states the point precisely: "The task of the destruction of the history of ontology must therefore undo the misguided interpretation of the being of entities that has founded their ontological assignment as scientific objects of research. It must be accomplished as a different ontology, one which is more fundamental, in that it recalls long forgotten ontological assignment that precedes scientific research" [34].

Of course, even though modern science "required metaphysics as its foundation," it is often argued that (empirical) science no longer needs "to refer to philosophical characterizations of the real for its justification"; indeed, as Heidegger himself has said, "the emancipation of the sciences from their philosophical background is the most visible characteristic of the historical movement of the nineteenth and twentieth centuries" [35]. There is a problem with this claim from science, however. At issue for post-metaphysical thinking in relation to the methodology of modern science is the tendency of the latter to metaphysical reduction, consistent with modern science's uncritical appropriation of the analytical dichotomy of subject-object that is central to the metaphysics of modernity. "It is...an understanding of Being as presence [i.e., perceiving/ conceiving/disclosing beings merely with reference to the present mode of time] that allows the constitution of objectivity in the different sciences" [34]. This is the understanding of reality that the sciences give us, consistent with their tacit ontological presuppositions carried forward through the diverse methodological

\footnotetext{
${ }^{6}$ Alternatively, see Rouse [33], who argues "not merely that Heidegger made significant contributions to philosophical understanding of the sciences, but that philosophy of science was at the center of his project and its development throughout his career." This claim can be appreciated once Heidegger's project is situated "with respect to the epistemological anti-naturalism that was central to neo-Kantianism and Husserlian phenomenology."
} 
commitments manifest in research projects. But, as Richard Matthews observes, while "the sciences have maintained the subject-object perspective of metaphysics," the problem is that "in the process of transformation, they have failed to retain the meta-critical capacity which is one of the fundamental attributes of metaphysics" [35]. The consequence of this failure of meta-critical capacity is that "all things [in the physical world, including the human being] are interpreted technologically," and "understood in terms of their social use or utility" [35]. Consider the point being made here:

This is not to say that there is anything inherently wrong with technology. The difficulty is that the scientist, viewing the world from the subject-object perspective, becomes unable to conceive an alternative way of thinking. Tied to the technological way of thinking, the scientist, and by extension most of the contemporary world, lacks the ability to think outside this mode of thought. In scientific debate, there is endless discussion of the nature and validity of theory, but technology as such is not in question. A scientist does not question whether the real is quantifiable. Rather, the validity of mathematics is presupposed as the necessary starting point of any scientific analysis. A particular theory may be questioned and even discarded, but the adequacy of mathematics as a depiction of reality is not. [35]

Heidegger states the point that is important for the present analysis: the conception of reality given here is that which conceives of all beings as present "in the sense of calculable material" [36]. In short, the dominant mode of engagement of beings is through a calculative thinking (rechnendes Denken) that seeks to become total, to the exclusion of all other modes of thought. Accordingly, "The difficulty for contemporary humanity is that as long as science is regarded as pre-eminent or privileged, it is much more difficult to step outside of technology and think of Being in a new manner" [35].

Heidegger, in his Letter on Humanism [37], observes that modern metaphysics interprets the human to be a rational animal (animal rationale), an interpretation that conditions modern science's conception of the human being in terms of the duality and interaction of mind and body. Heidegger argues against this metaphysical conception, asserting: "The body of man is essentially other than [that of] an animal organism. The aberration of biologism is not thereby overcome even by the fact that one annexes the soul to what is bodily in man, the mind to the soul, and the existential to the mind.... That the physiology and physiological chemistry [biochemistry] of man as an organism can be investigated in a natural scientific way is no proof that the essence of man lies in this organicity, that is, in the scientifically explained body." The point here is not to confuse the essence of the human being with the scientifically explained body. Neither must one accept a reduction of the human to such a scientific explanation, whether as a project of theory or experiment. The whole of Heidegger's thought works to overcome (Überwindung) this conception, and thus to abandon the subject-object dichotomy and mind-body duality, and to lead away from the intensified objectification of the human as a thing merely present-at-hand for a cognizing subject. This overcoming of metaphysics occurs first in and through language, inasmuch as the essence (Wesen) of the human and of the whole of being is 
thereby disclosed. The language of metaphysics and modern science is central to the disclosure of our world, but it is the manner of this disclosure that is subject to interrogation, insofar as the modern conception of the human ignores more fundamental (ontological and epistemological) questions. That is why Heidegger, in an essay entitled "Modern Science, Metaphysics, and Mathematics," states that insofar as modern science engages both facts and concepts "the way the facts are conceived and how the concepts are established are decisive" [38].

Given the presumed independence of modern science from philosophy, contemporary scientists who are steeped in their research projects and guided by their scientific methods often ignore an important point: "a fact is only what it is in the light of the fundamental conception, and always depends on how far that conception reaches" [39]. This holds true for contemporary developments in molecular biology, and thus also for technological developments consequent to recombinant DNA research generally and stem cell science in particular. Heidegger gives the examples of Niels Bohr and Werner Heisenberg, who distinguished themselves as scientists of their day not merely by the theoretical or experimental physics they performed but by the fact that they could and did "think in a thoroughly philosophical way" - "therefore [they could] create new ways of posing questions and, above all, hold out in the questionable." To hold out oneself, as scientist, in the questionable is a comportment of interrogation that questions the research paradigm itself as well as the facts and concepts. Equally, if not more, important is to interrogate "how and in what sense calculating and measuring are applied and carried out, and what importance they have for the determination of the objects themselves" [37].

To determine objects by way of calculation is to disclose the centrality of the scientific method-"the procedure, i.e., how in general we are to pursue things (methodos), decides in advance what truth we shall seek out in things." It is, says Heidegger, "the primary component out of which is first determined what can become object and how it becomes object" [38]. Things become objects for a cognizing subject; e.g., scientists theorize and experiment via a projection of their being, asserting what they are and how they are. In The Question Concerning Technology, Heidegger highlighted the problem of interpreting the human being as if a thing merely "present-at-hand" (Vorhandensein, e.g., such as a tree is) and then again as a thing "ready-to-hand" (Zuhandensein, such as tools or equipment). Consistent with developments in technology, especially biotechnology, all beings are gradually (though not inevitably or unavoidably) being brought into view as "standing-reserve" (Bestand)—things in general are engaged as "something orderable" (bestellbar) and subject to this or that disposition (being disclosed, exposed, reposed/re-positioned, transposed, disposed) consequent to human interests. There is, for Heidegger, a twofold danger here: (1) "the danger is that the human being will 'pursue and put forward only what is revealed in ordering and take all of its standards from there," and (2) "every other possibility of revealing [i.e., the way the human conceives or perceives, thus discloses or un-conceals beings] will be driven out and concealed" [40]. Rex Gilliland cautions, appropriately, that the human being is not "merely a passive participant" in the way beings are revealed [40]. Instead, the human is central to all ontological disclosure, and thus 
the human (e.g., as scientist, as philosopher) is central to all stipulations of the ontological status of beings.

In his 1953 lecture on Science and Reflection, Heidegger essentially calls for a change of comportment: "Even if the sciences, precisely in following their ways and using their means, can never press forward to the essence of science, every researcher and teacher of the sciences, every human being pursuing a way through a science, can indeed move, as a thinking being, on various levels of reflection and can keep reflection vigilant" [41]. That call was recognized and taken up in 2001 at the 35th Annual Meeting of The North American Heidegger Society with the theme, "Modern Science and Technology." The theme was pertinent to the transition into a new millennium and the question of human destiny in the face of the essential connection of science and technology. The question of destiny comes to the fore given the dominant role of science in society today, even though, as Heidegger's predecessor Edmund Husserl argued, "no empirical science could establish the meaning and validity of scientific claims themselves" [33]. Heidegger, consistent with his phenomenological insights into the metaphysical foundation of modern science, accepted this claim. But he also challenged modern rationalism and biologism, insofar as these perspectives uncritically carried forward "dogmatic constructions" (as he noted in Being and Time), viz., mind (qua subject) and body (qua object) as an indeterminate unity of animality and rationality, the indeterminacy of which was to be settled (presumably) in the epistemological debates of rationalists and empiricists. There is a hermeneutic presupposition at work in Heidegger's critique, viz., that all human understanding, including that of the scientist, is achieved only relative to a "context of signification" that is necessarily both factual and conceptual. Thus, Heidegger expects that "the authentic [eigentlich] movement of the sciences takes place in the more or less radical and self-transparent revision of their basic concepts. The level of a science is determined by the extent to which it is capable of a crisis in its basic concepts" [39].

Heidegger's concern here reminds one, of course, of the work of the historian of science Thomas Kuhn, who distinguished between "normal science" and "revolutions" in science, the latter occurring consequent to shifts in paradigms. Commenting by way of incidental comparison, Joseph Rouse writes, "For Kuhn as for Heidegger, 'normal' science avoids controversy over fundamentals in order to develop with greater detail and precision its unquestioned conceptual and practical grasp of a domain of entities. Left to their own devices, both [Heidegger and Kuhn] thought, the sciences suppress any fundamental questioning of how their domains constitute fields of possible inquiry" [33]. Applied to developments in molecular biology, one can say that stem cell science moves forward by attending to an iterative effect of facts and concepts available to it in the course of experimental design, taking the molecular as a domain of entities it may legitimately disclose, expose, repose, transpose, and dispose-as illustrated by all recombinant DNA techniques, including somatic cell nuclear transfer (SCNT). Stem cell scientists review developments in their field of research in terms of experimental procedure (which concerns the efficacy of techniques and reliability of experimental results) this is its "normal science," presumably already warranted by the prior "theoretical 
contextualization" of the research. But the appropriated theoretical context is not entirely what is fundamental or even enigmatic to this scientific enterprise.

Controversy today is to be found at the level of conceptual innovation as well as experimental design, thus one encounters the common criticism of stem cell research on the basis of its anticipated and desired societal impacts. This may not now be a controversy over the fundamentals of the science of molecular biology or even of human embryology as such. Nonetheless, the temporal comportment of stem cell research as futural (i.e., concern for the future of medicine as regenerative medicine) calls for reflection on those fundamentals if the science is to show itself adequately interrogatory from the perspective of meta-critique, such as concerns Heidegger. Such a critique interrogates the presumed normative validity of the research enterprise that is stem cell science, not merely with reference to its experimental domain, but also and especially with reference to its historical context of signification (its "historicality," as Heidegger would say). Despite its "progress" and "productivity" as science-i.e., disclosing the complexity of the molecular "world," even as a disclosure of part of what is bodily in the human-scientific knowledge does not eliminate the enigma that is the human being beyond his "embodiment." For Heidegger, that which is enigmatic in the human remains ever incomprehensible despite the progress of scientific research, for the enigma is beyond the as yet undetermined unity of animality and rationality that modern metaphysics thematized and sought to answer.

Consider, then, that in the same way that Heidegger says, "we can open a clock and examine it" and then ask "Where here is time?" [42], so we can "open" a body, extract a cell, examine it, and yet ask "Where here is the human?" That is not a question the stem cell scientist will ask readily, given his project. John D. Haynes states the point thus:

At the level of thing-ness (physicality, everyday, place, being-in-the-world) if you pull a functioning clock to pieces and put it back together again either in its same configuration or in a different but nevertheless functioning configuration then clearly you understand it. But can you be said to know it? Knowing it entails experiencing it as meaning. In knowing it the part cannot function as the whole: the clock is, in this sense, without why. The clock itself either as a hundred separate parts or as a hundred parts linked together is no more than a thing.... But when the clock works it signifies something else: the present becoming the past or the future becoming the present. At the level of being, understanding what it is that makes it tick does not of itself establish a meaningful connection with what it signifies (or points to).... The reality (meaning) of Time appears in the appearance or guise of the clock as the object of thought and when its meaning is preserved intact, then, and only then, do we know it. [43]

The analogy with stem cell research is clear: if one takes a functioning human embryo developed in vitro as part of a procedure of in vitro fertilization, removes from this embryo a stem cell, then manipulates that cell (perhaps numerous others like it) with any number of techniques of cellular modification (such as nuclear transfer), then one (as stem cell scientist) can be so focused on understanding the 
cell biology that one fails to see the meaningful connection of the stem cell to what it signifies (or points to).

Explanation relative to a concept of causality is important to the basic sciences and to medical "practice" in its appropriation of these sciences. Explanation, of course, is part of the methodological commitment of cell biology and the stem cell research project. Consider (stem cell biologist) Kevin Eggan's characterization of his research enterprise:

The genome is not merely a passive repository of genetic information. Chromosomes are dynamic entities undergoing structural changes that underlie development and cellular differentiation. We are interested in how developmental and environmental cues induce heritable variation in chromatin structure and how these variations regulate developmental potency, cell-fate and gene expression.

The development of the fertilized zygote into a complex organism has traditionally been understood as a unidirectional process, with cells in the embryo becoming gradually more committed to a specific tissue type. However, nuclear transfer experiments have demonstrated that the mammalian egg can relieve the constraints imposed by cellular differentiation and return the nucleus of an adult cell to a totipotent embryonic state. This process has been termed nuclear reprogramming. The primary research focus of our group is to understand the mechanisms by which reprogramming occurs. In particular, we wish to determine the nature of epigenetic information that is reprogrammed (i.e., aspects of DNA methylation and chromatin structure), the times at which reprogramming events occur and the identities of the molecular machinery that accomplish reprogramming. [44, italics added]

In the case of the research that Eggan describes, scientific explanation remains at the level of the "anonymous" body and its cellular components, i.e., at a level of experimental/conceptual reduction designed to explicate the stem cell scientist's "objective" experience. In this experience, there is a "natural" organism-the fertilized human zygote-the development of which has been observed and explicated by developmental biologists (human embryology). This natural process has been observed to be unidirectional from zygote to blastocyst to fetus, etc. Now, stem cell biologists such as Eggan are on a quest to reverse the "natural" (unidirectional) process of organic development of cells extracted from human embryos by "using nuclear transfer and other approaches" of cell modification. Seen as technique, this goes well beyond a mere observation of a natural phenomenon.

Of course, as Hub A. E. Zwart reminds us, "Appealing to nature has come into discredit in ethics and in public discussions" [45]. Nonetheless, what is natural retains its relevance. Zwart argues, "the notion of naturalness is still part of our moral experience... [W] hen we abandon any appeal to the moral significance of our biological nature, we are no longer able to express essential aspects of our moral experience." Going beyond what is "calculative" in a thinking that abandons the relevance of the natural, and staying consistent with a Heideggerian turn to "essential" thinking (wesentliche Denken), Zwart asks, "To what extent does a 
person have a right to interfere in his or her biological nature?" ${ }^{7}$ Engaging the issue of the natural that is challenged by genetic modification, D. W. Lauer puts the argument this way: "Leaving aside the residual issues of alleged benefits and possible misfortunes, I suggest that genetic modification is something fundamentally different in scope from traditional techniques of animal and crop selection. The difference lies in the Aristotelian understanding of what a thing, in fact, is." Lauer reasons that (1) "a thing...is what it is by virtue of its specificity and ability to maintain itself with particular limits (peras) that keep together their integrity and give them definition," and (2) "GM technologies violate the organic limit of the organism and force that organism into instability where it is neither itself nor clearly something else." Lauer thus concludes, "This instability...can be understood as a loss of foundation and grounding" [46]. Biologists after Darwin understand a move from "natural selection" to "artificial selection." Yet, as Lauer points out, "Even artificial selection could not violate nature's laws of reproduction." But, with genetic engineering, such as by nuclear reprogramming, we have an intentionality (belonging to the scientist) that would (if it could; if it should) control a molecular process for a presumably noble purpose given the pressing human interest in regenerative medicine. Eggan's quest in the laboratory, therefore, discloses not a natural experience, but instead, what Lauer calls "an engineered experience."

This engineered experience begins with the IVF techniques that generate the excess embryos. As Evert van Leeuwen reminds us, "The existence of the human embryo outside the womb is in itself a human artifact and its being totally dependent on the circumstances in a scientific and technological context. Outside the womb it cannot develop into a fetus, a child or an adult" [14]. With the engineered experience of the stem cell extracted from a human embryo, we are witness to "a transformation in our ontology of life in general." For with the transgression, such as through nuclear reprogramming, of a natural law of (unidirectional) reproducibility, a natural "existential determinacy" (what Aristotle understood as the teleology of nature and what a molecular biologist understands as the cell's natural unidirectional development) quickly becomes "indeterminate," not only at the cellular level but also at the level of the life-world (Lebenswelt). Lauer writes that "Heidegger, in accordance with Aristotle, finds a limit to be an internal safeguard on a thing by maintaining its identity. Evidently, the limit of a thing gives an entity specificity and stability to make a claim to its own uniqueness. A limit, thus, is not a defect or deficiency in a being. On the contrary, it is a beginning of a thing that comes to stand on its own internal order of change and form" [4]. In nuclear reprogramming, we have a presupposition that serves as the scientist's projection of an as yet unattained but desired reality. In Eggan's case, genes responsible for human neurodegenerative disease (e.g., amyotrophic lateral sclerosis (ALS), known as Lou Gehrig's disease) may be exposed and then re-posed or trans-posed through such reprogramming, thereby providing "valuable model systems for the in vitro study of these diseases," i.e., "changing adult cells back into embryonic-like stem

\footnotetext{
7 Zwart argues that to retain appeal to the natural is not to advance a "naturalist" argument, but that “...naturalism posits that univocal moral acts can be deduced from a biological order of being. This denies the constitutive activity of practical rationality; it is the duty of practical rationality to interpret the moral significance of biological data" [45, p. 73].
} 
cells and then differentiating them to the needed cell type" [47], such that the relevant research result may be translated into therapy. But as Lauer adds, "As Heidegger follows Aristotle, there, indeed, does seem to be the possibility for the misappropriation of beings, of using beings unwisely, which would be violating the organic limits that fix the thing as what it is. Using beings unwisely potentially means transforming beings or turning them into mere functions within an economy of control. This would somehow deform the constitutional originality and stability of an entity in favor of an outside author" [46, italics added]. With stem cell research, it is already known that the various techniques in use deform originality and stability given the high risk of oncogenesis due to "the continued presence of transgenes encoding oncogenic factors and delivered by oncogenic retroviruses." 8

For the most part, a research project (such as that of Eggan) leaves aside the hermeneutic of existence that is essential to human ways of being, which necessarily goes beyond the question of means ("Is genetic engineering (nuclear reprogramming) safe?") to the question of ends ("Should we engage in this kind of research?"). As Regine Kather observes, "Qualities hidden to our ears and eyes can be made visible; yet in process they are quantified. Objectivity in the scientific sense of the word can be achieved only if a theory is based on data independent of all reference to human beings, to a first- and second-person perspective. In order for a measurement to be reproduced at any place and time and by any persons, all qualified sensations must be excluded, as well as bodily expressions of intention or meaning, emotions, aims, and even values" [49]. The same exclusion occurs in the explanatory schemes of stem cell science. ${ }^{9}$ Douglas Melton, co-director of the Harvard Stem Cell Institute, for example, can assert, "all human cells, even individual sperm and eggs, are "living" [51]. This is a scientific claim, as is Melton's further claim that, "from the scientific perspective, this work [stem cell research] holds enormous potential to save lives, cure diseases, and improve the health of millions of people." But, Melton goes beyond the domain of his scientific competence when he adds, "The relevant question is "when does personhood begin?" He concedes as much when he opines, "That's a valid theological or philosophical question." It is, in short, not a question to be answered by science, certainly not by stem cell biology.

One consequence of the presumed exclusion of values from scientific research such as that being pursued by Eggan or Melton is that, "no ethical statements can be derived from the scientific concept of being" [49]. Thus, no ethical statements can

\footnotetext{
${ }^{8}$ Kit Rodolfa adds, "While the recapitulation of this technology in human cells could address two important challenges currently faced by the stem cell field, the need to avoid immune rejection by creating pluripotent cells genetically identical to a patient and objections of some to the use of surplus preimplantation human embryos, this demonstrated connection to oncogenesis presents for now a significant barrier to such application." The issue of identity is itself noted here: "[nuclear reprogramming research] may be able to inform us about fundamental mechanisms of cellular identity. How amenable is cell identity to being altered in this fashion? Can this approach be generalized to reprogram a variety of different cell types?" See also Shimya Yamanaka [48].

9 The question of objectivity presupposes a philosophical debate, as yet unsettled, among philosophers of science committed to the defense of realism ("science gives us an account of the functional demarcations of the universe as it is in itself") or constructivism ("nature must be a cultural creation"). For a discussion with reference to Heidegger, see Dreyfus [50].
} 
be derived in a straightforward deduction from the stem cell scientist's concept of the entities he discloses, even from that which he calls "blastocyst." Yet, the disclosure of the blastocyst does not remain at the level of the scientific techniques in use, insofar as the concept "blastocyst" merges with the concept "human embryo" and initiates an interrogatory move from the molecular level of engagement to the level of lived human experience, thereby a move from scientific assertion to moral evaluation. Melton's evaluative assertion takes him outside the domain of scientifically grounded assertion when he says, "The reality of the suffering of those individuals [having chronic degenerative diseases] far outweighs the potential of blastocysts that would never be implanted and allowed to come to term even if we did not do this research." Melton here measures the quantity or quality of the suffering of many persons against the quantitative/qualitative potential of the blastocysts that are unavoidably destroyed in the extraction of stem cells. Tacitly, he performs a utilitarian calculation, privileging present and future persons suffering from disease over blastocysts that are mere remnants of an IVF process ("mere" because they are not to be implanted in some woman's womb and carried forward to full term).

But, Melton's evaluative assertion also makes the point at issue here: to see properly the meaningful connection of the stem cell to what it signifies (or points to) is to see that this signification itself is not molecular at all; the human beings for whom this science and technology are being pursued are never reducible to their bodies or to their cell biology. The ontology that is ever present here is not merely the "gene ontology" with which the scientist engages and "represents" (vorstellen) the objects of his research $[52,53]$. Rather, one can ask, as Peter Wilberg does, whether "illness is a purely biological phenomenon with an 'organic' or 'genetic' basis." Then, pondering such a question, one may "see illness as something that does not merely have a specific cause in the human body but a specific meaning for the human being.... A phenomenological investigation of illness would explore the close relation between illness and identity, the felt body and our own felt sense of self, our immune system and its defences and the mental defences we erect to preserve a singular stable sense of identity" [54]. Wilberg is here pointing to Heidegger's insistence that the human body is "no mere bounded biological 'bodyobject' [thus, Körper] but a living embodiment [thus, Leiben] of the human being" [55]. This embodiment or "bodying-forth" of the human, Heidegger says, is "irreducible to mechanisms" [55].

Surely, the science at work here promises to contribute to this or that patient's need for techniques of "regenerative" medicine, assuming the hypothesis of nuclear reprogramming in the laboratory will lead to reliable therapeutic results at the bedside. Yet, as a human being (read here present indicative sense, not substantive present sense), this or that patient lives in a world of his or her own lived possibilities of being, with the unique yet relational worldly significations those possibilities entail. All of this encompasses that individual's potentiality for being, itself much more than the individual as patient or research object. It is in relation to this potentiality that science-stem cell science-must face interrogation about the normative validity that it presumes to have. 
Central to normative validity is a distinction between the scientist's acquaintance with the objects of his research in the micro-setting of the laboratory and the meaning of that research in the non-theoretical, more encompassing, historical context of his responsibility as a human being sharing a public "world" of diverse engagements. The former is dependent on the scientist's projection, given in the experimental design he sets up: "Experiment begins with the laying down of a law as its basis. To set up an experiment means to represent a condition under which a definite configuration of motions is trackable in the necessity of its course, i.e., to being controlled in advance by calculation" [20]. This is the scientist's calculative thinking (rechnendes Denken), to be challenged, however, by an "essential" (wesentliche) or a "reflective"/"meditative" (besinnliches) thinking that is pursued in meta-critique. The logic of the former should be alarming for the fact that, "with the help of its results, it adapts itself for a new forging-ahead..."-i.e., research finds itself "having to adapt itself to its own results" [56]. (In fact, today, it is meaningful to speak of a structural transition from reductionist molecular biology to a more integrating "systems biology" [57].) The moral conundrums that continue to be at issue in stem cell science (developments such as those cited at the outset of this paper) are a demonstration of this phenomenon. Heidegger calls this phenomenon, "securing the precedence of their [the sciences'] way of proceeding (Verfahren) over the entities (nature and history) that are being objectified in research" [56]. Rouse states the consequence relative to the meaning of the research enterprise: modern science and technology are akin in that "each relentlessly overrides any [wider normative] accountability that might constrain the expansion of its capacities for calculation and control" [33].

\section{Recent "heideggerian" commentary: Brassington and sloterdijk ${ }^{10}$}

Consider what Brassington means by "reductionist" metaphysics as disclosed by medical practice (understood as iatrikêtechne). The first point he makes is that: "In a medical context, disease, healing, aging, and so on can be reduced to, or replaced by, biological or chemical processes" [1]. These are ways in which medical practitioners engage their subject matter. But, this is consistent with a conception of modern technology such as that which concerns Heidegger: "In a nutshell, modern science reduces things to their constituent parts and modern technology is concerned with moving those parts around and into a certain order" [1]. This reduction is problematic when the human being is conceived metaphysically merely according to the mind-body dichotomy. The body and mind (reduced to brain matter as neurochemical structure), in their constituent parts, are then disclosed to be subject to technological manipulation and ordered as made possible by science and technology, even when there is significant doubt present about the intention and consequence of such manipulation.

\footnotetext{
10 A note of clarification: By "Heideggerian" I do not mean a commentary that is either ideologically or uncritically committed to Heidegger's existential phenomenology. I mean simply a discourse that is informed by his thought with a view to sorting out implications that bear upon bioethics.
} 
The more fundamental problem, as disclosed by stem cell science, however, is implicit in Brassington's general statement about the effect of the reductionist attitude: “...if the 'true' account of the world is reductionist, then there seems to be little space for the human: a human is just one animal among many..." [1]. In other words, to conceive the human being merely as animal, even as rational animal-i.e., to conceive the human merely as a unity of animality and rationality-is wholly problematic from the perspective of the existential phenomenological critique of the modern metaphysical project. The very fact that medical practitioners seek to implement technologies that manipulate the human as "mind-body" (an assortment of constituent biological and chemical processes) means that the human's mode of being is reduced to that which is body and mind as conceived by modern metaphysics. The human is thereby subject to all modes of "disposition" (i.e., becomes disposable) in the same way that any animal is merely a "stock" resource ("ready-reserve," Bestand, as Heidegger would say) for human disposition, for processes of commodification.

With reference to stem cell research, Brassington makes one observation: "we might conclude that sperm and egg banks treat persons and gametes as a reproductive standing-reserve" [1]. This would be true for both embryonic stem cell material as well as induced pluripotent cell matter, which have human interest as "stock" matter (standing-reserve) for reproduction (manifest in IVF technologies as well as stem cell therapies actual or prospective in efficacy). ${ }^{11}$ The question here, for medicine, is how to conceive the human being properly without "disempowering medicine's ability to heal," as Brassington says.

Sloterdijk and the "anthropotechnological" codex

Consider an academic controversy that had its airing in the public media of Germany. William Saletan wrote an essay for the Washington Post in June 2007 that is perspicuous for its title "Making Manimals," and which links to what has been called "the Sloterdijk debate" in Germany:

We've been transplanting baboon hearts, pig valves and other animal parts into people for decades. We've derived stem cells by inserting human genomes into rabbit eggs. We've created mice that have human prostate glands. We've made sheep that have half-human livers. Last week, Britain's Academy of Medical Sciences reported that scientists have created 'thousands of examples of transgenic mice' carrying human DNA. According to the report, 'the introduction of human gene sequences into mouse cells in vitro is a technique now practiced in virtually every biomedical research institution across the world.'...

According to the British academy's report, 'researchers have constructed ever more ambitious transgenic animals' — some with an entire human chromosome-

\footnotetext{
11 Indeed, Alex Mauron speaks similarly of "genomic metaphysics" [58]; he postulates, "the unspoken premise that to engineer the genome of future persons in such a way that the genome of every cell is affected (by germline engineering) somehow has more ontological clout than to effect some indirect phenotypic change."
} 
and it's 'likely that the process of engineering ever larger amounts of human DNA into mice will continue.'...

We're not doing these things because they're creepy. We're doing them because they're logical. The more you humanize animals, the better they serve their purpose as lab models of humanity. That's what's scary about species mixing. It's not some crazy Frankenstein project. It's the future of medicine. [59]

Saletan's remarks point to what is central to this therapeutic research-it is conceived as a logical project of bioscience despite concerns about recombinant technologies "transgressing" species boundaries. But, more telling, the logic here is the logic of modern metaphysics, manifest in what Heidegger calls "calculative thinking" (rechnendes Denken); it is a reductionist logic that seeks to disclose and dispose of biochemical processes of mind-body merely according to a scientific model of what it is to be human. ${ }^{12}$

As Babette Babich says concerning Heidegger's characterization of the scientific research project:

[T] he experiment requires a preestablished rule, a stipulated law, and this is the basis of calculability and thus of calculation: "To set up an experiment means to represent or conceive [vorstellen] the conditions under which a specific series of motions can be made susceptible of being followed in its necessary progression, i.e., of being controlled in advance by calculation." And because such an experiment is the expression of a projected law, one has both a criterion for as well as a limitation upon possible results. This is of course the possibility of measurement and this is essentially not observation per se. [60]

Thus, the human is conceived, even as the animal (mouse, pig, rabbit, etc.) is conceived, as some "thing" (body) that is merely present at hand (Vorhandenheit) despite claims of accounting for personhood and autonomy in the research participant. Margrit Schildrick captures the problem even in bioethics when she writes, "bioethics is out of touch...with bodies themselves, in the phenomenological sense in which the being, or rather the becoming, of the self is always intricately interwoven with the fabric of the body" [61]. Science, in short, is regnant in determining the ontological status of the human being largely through this emphasis on animal nature. Science is also regnant in its relation to bioethics, as the latter discipline falls behind the pace of scientific research and finds itself reactive to, rather than guiding, bioscientists on the moral boundaries of rapid developments in molecular science and associated or derivative technologies.

It is precisely this project that, in part, motivated the German philosopher Peter Sloterdijk to deliver an important speech, albeit controversial for "German academia," in the summer of 1999 entitled Regeln für den Menschenpark: Ein Antwortschreiben zum Brief über den Humanismus (Rules for the Human Zoo: A Commentary on the Letter on Humanism). The title of Sloterdijk's talk refers to

\footnotetext{
${ }^{12}$ For a discussion of Heidegger and changing historical conceptions of science, see Babich [60].
} 
Heidegger's well-known essay of 1947 that offers a critique of the doctrine of classical humanism, i.e., articulated as Plato's "doctrine of truth" (with its ontological and epistemological presuppositions and ethico-political motivations) that governs, as architectonic doctrine, the Western philosophical tradition.

Sloterdijk's remarks have been reviewed by Mary Rorty, who concerns herself with "the role of bioethics — and bioethicists - in public controversies." Rorty finds in Sloterdijk's discourse a concern with what is at stake in humanism, viz., "the specification of man with respect to his biological capacities and his moral ambivalence." She identifies "two ambiguities" in Sloterdijk's discourse:

One was the distinction-or is it really a conflation-of a descriptive "anthropotechnological codex" which is currently in the process of being written by geneticists and biomedical scientists-a book currently far from completion, but already productive of a cascade of predictions and hopes; and "the rules for the human zoo"- - the normative stipulations about what kind of genetic experimentation, research and intervention will meet ethical standards for the protection of human subjects and human rights. [62]

Rorty then asks the salient question that is suggested by Sloterdijk's oblique discourse: "Did he [Sloterdijk] really think that knowing what was possible was directly equivalent to determining what could be allowed?"

This is a central question for anyone concerned with developments in genetic engineering, stem cell research, and the host of technologies being translated into therapies. Scientists working in this domain continue to press at the limits of an inviolable human finitude, seeking to know what is possible of their projects of uncovering the elements, forces, and processes of "nature" (in its reductionist sense). So an attitude of moral ambivalence among some scientists and the public yields to a strident thrust at possibility, a thrust without an adequate conception of the human being. The inadequacy of both utilitarian and deontological moral theory in the face of these bio-possibilities makes the confounding problem all the more urgent; what could be allowed is willy-nilly installed as if it should be allowed, and more often than not, installed as a matter of drift if not by explicit design in the sense that the latter is the outcome of deliberative discourse (e.g., in public consensus on a policy of eugenics, even though eugenics may issue as an occult practice and thus as a violation of norms of research integrity). ${ }^{13}$

Yet, as Sigrid Graumann says, "It is a part of the concept that democratic societies have of themselves that the public negotiates the legitimacy of scientific and technological innovations, and political decisions are expected to refer to public opinion" [3]. When public opinion is less deliberative than it can be and is much more deferring to the anthropotechnological "codex" being installed by scientific research, then the scientific model of the human becomes total ("driving out every other possibility of revealing" [41]), and the authority of public opinion is

\footnotetext{
13 Recall here the case of the South Korean scientist, Hwang Woo Suk of Seoul National University, accused in December 2005 of fabricating research results in what at the time was considered "a landmark study" in human embryonic stem cell research (therapeutic cloning involving individualized stem cell lines). His report was initially published in the journal Science in May 2005. See here Demick and Kaplan [63], Resnik et al. [64], and Rossner [65].
} 
marginalized or, worse, ignored. The future of the human species is then determined wholly biologically through the impulse of bioscience's technological instrumentality. This presents an immediate challenge to bioethicists, for the "question of which social reality we want to live in the future is entirely a question of ethics. The aim of applied ethics should therefore not be reduced to the evaluation of concrete and currently relevant innovations in the biosciences and biomedicine. Applied ethics can not escape being involved in the creative processes of dynamically changing social values and norms, world-views, and collective conviction and belief systems" [3].

This engagement with changing social values was at the heart of Sloterdijk's lecture, even as he sought to move beyond Heidegger's views as laid out in the latter's "Letter on Humanism" [11]. But, for Heidegger, this would mean questioning the Western metaphysical tradition according to which humanity is conceived merely as a unity of animality and rationality. It would mean understanding first of all that this unity is by no means determined merely because it is conceptualized, but that it may be determined by the regnant claims of science and technology, and may thereby undermine the "authentic" disclosure of the human way to be.

The relevance of "authenticity" (Eigentlichkeit)

"Authenticity" is a concept introduced by Heidegger in his magnum opus, Being and Time (1927). It is a concept that differs importantly from Kant's concept of autonomy, as well as the "Kantian" concept of autonomy that has become a basic principle of medical ethics. ${ }^{14}$ For an exemplary engagement of the concept of authenticity as it applies to medical ethics, let us review briefly what Jos Welie has to say [67].

Welie begins by stating an important observation in line with Heidegger's thought: "Since it is impossible to know what is in the best interests of other human beings, they themselves should determine their own course of life" [67]. This statement relates immediately to Welie's further observation that there is in contemporary bioethics discourse inadequate engagement of the underlying philosophical anthropology. When this is engaged critically one finds that the so-called "virtue of selfsufficiency" proper to libertarian political and moral philosophy is conceived such that "any social acts will always be a matter of charity or philanthropy, being therefore not obligatory" [67]. The concepts of autonomy and duty thereby lose their purchase in most, if not all, social and political relations and moral deliberation. Yet, the practice of medicine is concerned with individuals who, as patients, are not selfsufficient with respect to the management of their disease and well-being, both physical and psychological. The individual as patient, even as research subject, is sometimes subordinate to the conditions of life, despite appeals to autonomy and the right to his or her own "creative power" or "freedom to shape one's own, worldly life" [67].

$\overline{14}$ For the distinction between these two concepts of autonomy, see Secker [66]. 
At this point it is important to distinguish two concepts from Heidegger's thought: (a) thrownness (Geworfenheit) and (b) resoluteness (Entschlossenheit). Welie states the former in a reasonably understandable way, as follows:

A human not only is a creative being; there is also the facticity of human existence. The human being is "thrown" into life from the very beginning of conception. There is a particular physical and psychological constitution and health status that are "givens" to a large extent. There is historical, geographical and social situatedness which, even if changed in the course of life, is always exchanged but never undone. And then there is an even more fundamental "thrownness": Whatever free choices individuals make, they must always choose between alternatives, and once made, the choices are unchangeable. This irreversibility of time constitutes a significant limit to freedom. [67]

The above contrasts with the concept of resoluteness, which for Heidegger relates conceptually to a human way of self-disclosure or "disclosedness" (Erschlossenheit) [39]. Resoluteness is anticipatory in the sense that it is an attitude of projecting one's self-potentiality, i.e., possibilities of the self, without pretense of "escaping" the self's thrownness. As Steven Heine puts it, "authenticity is the sober anxiety of individualized Dasein [Da-sein, human being-there] fully founded within and realized on the basis of its finitude. 'Anticipatory resoluteness is not a way of escape, fabricated for the 'overcoming' of death; it is rather that understanding which follows the call of conscience and which frees for death the possibility of acquiring power over Dasein's existence and of basically dispersing all fugitive Self-concealments"' [68].

Precisely because every individual is engaged by the call of conscience (Gewissen) while at the same time occupied, even tacitly governed by, his or her thrownness, the individual is for the most part steeped in an attitude of mere following ("concernful curiosity") of an anonymous "They" (das Man) and thus "reticent" about taking up his or her own (eigen) possibilities of self-being. He or she for the most part does as "They" do according to an everyday averageness of "idle chatter" (Gerede) and concernful curiosity that lack committed and sustained interrogation. This reticence is itself a symptom of a fugitive self-concealment that must be brought into disclosure for the individual human's appropriation of resolute being. Thus, Heidegger distinguishes between being authentic (eigentlich) and being unauthentic (uneigentlich), the latter an obvious separation from the authentic self-disclosure through which authentic possibilities of a resolute self are envisioned and appropriated.

In short, the fact that the unity of animality and rationality is as yet undetermined-i.e., not determined even conceptually as part of the concept of metaphysical modernity-does not entail that humanity must move to such a determination. This, as we have noted in reviewing Brassington's remarks, is a metaphysical project that is wholly problematic from the perspective of critiques given in existential phenomenology, such as that of Heidegger. Thus, the reductionist metaphysics that is at the base of biomedical research, such as stem cell research, cannot be sustained. 
In the same way that one need not move in the direction of such a determination, one need not be complacent, illusory, or despairing about what such research portends for the human future-all of which Welie reviews in light of other existentialist thought (Sartre, Marcel). Rather, Heidegger's concept of anticipatory resoluteness takes on more critical application. Consider Welie's important observation from Heidegger's elucidation of human temporality: "the authenticity of human life can only be discerned when its temporality is not reduced to a series of present actions" [67]. This is precisely the problem with the reductionist metaphysics of biotechnology such as stem cell research and its associated ethical deliberation-human temporality is wholly ignored if not misconstrued, and thereby the possibilities of individual and collective choice are compromised from the beginning. Welie puts the point I wish to make this way in relation to Kant's or the Kantian concept of autonomy and its role as a fundamental principle of biomedical ethics: one problematic aspect of the concept of autonomy is "its tendency to focus on the present and to disregard the fact that human existence does not occur in time but is itself temporal. On the other hand, the notion of authenticity-if understood in the existentialist sense of the word-does reflect this portentous aspect of human being by understanding human choice as promise rather than indeterminateness" [67]. To say human existence is itself temporal and not "in time" is to forego conceiving time as a "thing" that is somehow merely and wholly "present." What does this mean more specifically? Welie answers:

Heidegger rejects any understanding of the past in terms of passed events: That would be a case of mistakenly thinking the past in terms of the present, a present gone by. Such a mistake is typical of everydayness as well as the scientific preoccupation with the measurement of time. It completely overlooks that it is only because of our past to which we can return, that we are able to plan ahead into the future.

In line with Heidegger's rejection of understanding the past as passed, we may add that the future is not "no(thing)." It is real in so far as it enables choice. But choice, unlike pure chance, is not a purely present phenomenon. My decision at a given moment to do A rather than B would not be a genuine choice if I had not the slightest certainty about what I was going to decide at the next moment. If my freedom were absolute in that the future is always fully open, I cannot plan (for the next moment upon conceiving the plan, I might decide something to the contrary). For my free choice not only to be free but to be a genuine choice, I must assume that my behavior in the moments to come will not counteract my present decisions. Thus, every decision I make about my own future has the nature of a promise. For there to be any sense in planning ahead, such planning must entail a consequent determination of the future and thus a limitation of my future freedom. Conversely, I must be willing to be determined by my own past choices. For there to be genuine free choice, I must freely limit my own freedom. [67]

This understanding of human choice applies equally, however different in degree, to both individual and collective decisions. It applies, therefore, also to ethical and policy deliberations about direction and expectations in a whole host of projects in 
stem cell research and genetic engineering more generally. When such research is governed by the reductionist attitude, the whole of human endeavor is reduced to an undetermined mind and body unity of constituent parts, all of which are taken as something merely present-at-hand and then as "ready-reserve" for manipulation by this or that investigator. The consequence is that the temporal aspect of the human being is forgotten at human peril, since the human being is never reducible to the merely present-at-hand unity of animality (body) and rationality (mind). "The essence of human life disappears out of sight if its temporal character is reduced to a series of present actions" [67].

\section{Engaging stem cell research post-metaphysically}

Fredrik Svenaeus is an example of one philosopher who has recently articulated a defense of therapeutic cloning via a post-metaphysical, i.e., Heideggerian, mode of argument. He is concerned to underscore "an ontology that does not limit itself to biological accounts, but instead focuses on the embryo's place in a totality of relevance surrounding and guiding a human practice," i.e., embryonic stem cell research [69]. In doing so, Svenaeus is attending to Heidegger's phenomenological instruction that a human life is intentional, filled with meaning that is at once "retentional" and "protentional." This meaning is manifest as a referential context of significations that always goes beyond the merely present-at-hand to account for both our human thrownness and our human anticipatory resoluteness. Thereby, a fundamental ontology of the human being, such as the one Heidegger sought to elucidate in Being and Time, accounts for human temporality without succumbing to the reductionist failure of seeing the human future as a mere autopoiesis (selffabrication).

Autopoiesis is not without its challenges in bioethics: “...there is a strand of contemporary thinking, discernible, for instance, in the writing of the more conservative bioethicists, which sees autopoietic ambitions of humans as the ultimate hubris, especially in debates on gene technology, cloning, embryo research, and the like" [6]. Therapeutic research that employs the techniques of recombinant DNA research is to be distinguished, as a matter of degree, from a program of eugenics that advertently pursues "de novo enhancement of human nature." Consider Alex Mauron's observation that links critically to the reductionist metaphysics identified by Brassington:

...the debate on eugenics is necessarily more narrow than the broader issues raised by the program of homo faber sui ipsius ["man, maker of himself"], the self-engineering of man. Nevertheless, it seems that whenever the issue of technological change of human nature is broached, the notion of eugenics comes to the fore. The broader, and in some sense more interesting, question of whether it is legitimate for mankind to reshape its own nature tends to be reduced to a narrower, genome-centered question, namely whether one should or not allow intentional genomic changes. This illustrates an important strand of current conventional wisdom: that the human genome is increasingly 
thought of as the "essence" of the human person and that if there is to be a self-shaping of human nature, the genome will necessarily be the principal substrate of this autopoietic endeavor. [70] ${ }^{15}$

What many contemporary bioscientists do not understand (simply because it is not their primary domain of directed research) is that the governing or "architectonic" discourse within which their research moves is one in which "the data of modern biology" are being introduced rather haphazardly into "the classical ontological framework" that begins with the ancient Greek ontology of "hylomorphism" (i.e., matter-form unity of body-mind/soul) and continues on into modern ontology in the concept of the human being as rational animal (animal rationale). This is occurring despite twentieth century and current post-metaphysical critiques, which is less a criticism of scientists working in cell biology than of bioethicists who fail to marshal philosophical thinking beyond superficial appropriations of modern moral theory (superficial because of inadequate attention to the ontological and epistemological bases of both utilitarianism/empiricism and deontology/rationalism). With the rise of science as a dominant mode of "knowledge" that is said to have authority beyond mere "useless thinking," such as philosophers are thought to do, some scientists of course believe what Heidegger finds faulty. One scientist, for example, argues "...Heidegger takes issue with the notion that can still be influential in analytic philosophy, namely that 'scientific thinking alone is the authentic, rigorous thinking, that it alone can and must be made the measure even of philosophic thinking", [60].

A post-metaphysical - in this case, existential phenomenological-thinking that properly grapples with the confounding challenges of stem cell research and genetic engineering must do as Heidegger proposed in Being and Time. It must lay the foundation of science in the sense of a "leap-ahead" (vor-ausspringen) solicitude (Fürsorge, "concern for") that allows science its proper role, but subject to a deliberative public discourse (Rede), rather than to this or that idle chatter (Gerede) that is the sort of mere curiosity that lacks real engagement and interrogation of the matter at hand. ${ }^{16}$ The point of a leap-ahead solicitude is to enable those engaged in the discourse to "become properly bound together (eigentliche Verbundenheit)," which then "makes possible the right relation to matters (die rechte Sachlichkeit)," and thereby achieves a "co-disclosure" (mitzuerschliessenheit) [19]. The idea of codisclosure expresses the unity of mutual contribution to the outcome of the matter at hand, and thereby, to the determination of the way in which humans are who they are (i.e., "co-exist" as "being-with," Mitsein). What matters is the interaction of each in the face of their mutual thrownness and anticipatory resoluteness before the future, always unknown, uncertain, and finite in its possibilities. Absent such codisclosure, as Sloterdijk (echoing Heidegger) puts it, "homelessness is the fundamental state" of the human being, manifest such that "misapprehensions in the apprehension of the self are the rule" [72].

\footnotetext{
15 Here Mauron speaks of "genomic essentialism," where the genome is assumed and socially represented to be "the ontological core of an organism, determining both its individuality and its species identity."

${ }^{16}$ For a different view, see Paul Kurz [71].
} 
Thus, the bioethicist who guides the bio-scientist with respect to moral implications of biomedical research cannot substitute himself (i.e., impose his determinate vision) for that of the bio-scientist-this would be a "leap-in" (einspringen) solicitude that is deficient in relation. Rather, the bio-scientist himself must understand that the research to which he commits himself always concerns, first and foremost, not a "what" (constituent part of a body, e.g., stem cell, embryo) but a "who" in his and her existence-beings who have their own individual (Da-sein) and collective (Mit-sein) projects of self-becoming that are not to be superintended by the scientist's research design as if it were some authoritatively totalizing constraint on the research subject's freedom to be. Further, and especially urgent, the research scientist must understand that through his research project he projects himself and other humans in a co-potentiality for being and thus commits himself and others to a specific ontological determination. It is in this sense that the research scientist is "responsible" and accountable to himself and to others in the mode of his solicitude, whether deficient (inconsiderate, indifferent, leap-in) or authentically caring. Thus, Heidegger says, "When Dasein stands resolutely open it can become the 'conscience' of others (Das entschlossene Dasein kann zum 'Gewissen' der Anderen werden)" [39].

The concept of conscience (Gewissen) as Heidegger understands it is essential to an ethics of responsibility and the principle of authenticity inasmuch as "this conscience is Dasein's very openness to the excess of possibility" [73, italics added], as Michael Lewis puts it-excess being precisely what is at issue in contemporary stem cell research and genetic engineering. The excess is present from the beginning in what is assumed to be the promise of "the technological fix" for what ails humanity, whether in therapeutic and regenerative medicine, or reproductive or enhancement genetic engineering. Here we have the threat of excess in the sense of dangerous possibilities through which the whole of humanity may be altered fundamentally according to such technological ("anthropotechnological") determinations. ${ }^{17}$

Hence, the instrumental view of bio-technology misses what is essential. Charles Sabatino observes, "Heidegger does not define technology strictly as an act of achieving; but rather as a way of revealing" [75]. Indeed, Sabatino adds,

At first glance, it may seem strange to refer to technology as a way of revealing. Nevertheless, the recent achievements with the genome and embryonic stem cells might actually help exemplify what Heidegger was trying to say. The genetic code has been spiraling away within the encasing of its double helix structure; and stem cells have been differentiating from out of their primal status to form living organisms since well before the arrival of humans within the world. Nevertheless, only quite recently have their

\footnotetext{
17 Consider, e.g., that the creation and use of pre-implantation human embryos "outside the womb" means that "the act of separation makes it possible to look at an embryo as a special kind of human tissue," even though "most of the ethicists and scientists who defend the instrumental position do not adhere to this view. They do not embrace the possible reduction of an embryo to a tiny piece of cellular tissue" - although, nonetheless, the embryo's "instrumental value... has to be measured by looking at the goal for which it is used." See here, van Leeuwen [14] and Sloterdijk's multi-volume, Spähren [74], wherein Sloterdijk speaks of "microspheres" of space-relation, such as that of the fetus-placenta.
} 
in-formational patterns been brought out of the secrecy of ages and translated (trans-late: transferred) into a language of intelligibility that can be deciphered through the lens of science and thereby made available to human scrutiny and manipulation. [75]

These are, from the view of scientific progress, "achievements." But these engagements of nature are always more than that at base: "We forget that our doing, by the very nature of how and where it takes place, is indeed a form of revealing" [75]. Research scientists and bioethicists are in need of a transformed comportment, one that keeps them ever mindful that their basic way to be is one of revealing worlds of possibilities; the biomedical sciences themselves are utterly revelatory in a push at the limits of possibility. Sabatino states the need rather starkly:

Heidegger says there is hope for the world if and as the danger is perceived as the danger. Somehow, the all-encompassing manner in which everything is now open and accessible, that there may be no limits to what man can do, and that all lies vulnerable might suddenly act as a lightning strike to shake us out of the slumbers of the everyday business. It might dawn on us that everything, including world itself is at risk; and thus we ourselves are at risk. Then we might understand that we ourselves are the danger. [75, italics added]

To say we are the danger is daunting enough. To realize that, as Sabatino adds, "the danger haunting the technological era is that there is no retreat" [75, italics added], is all the more revelatory of an occult anxiety circumscribing all human actions that are motivated by technological instrumentality, but especially actions that issue from the reductionist metaphysics incorporated into much of contemporary science, including stem cell research. Anxiety (Angst, "one feels ill at ease," "es ist einem un-heimlich"- "un-heimlich" etymologically also means to be "unhomely") here is a mood fundamentally different from the sort of fear (Furcht) that has its known object. ${ }^{18}$ In anxiety we are faced necessarily with both concealment and disclosure simultaneously, thus with ambiguity (Zweideutigkeit); and concealment and disclosure both have their untold consequences for the way the human world is configured by our individual and collective revelatory practices. Indeed, says Heidegger, "our concernful awaiting finds nothing in terms of which it might be able to understand itself..." [39]. In anxiety, one is faced with "the impossibility of projecting oneself upon a potentiality-for being which belongs to existence... Anxiety is anxious about naked Dasein as something that has been thrown into uncanniness" [39]. The purposes of stem cell research (therapeutic/regenerative, reproductive/enhancing), as projections of a human potentiality-for-being, are no less subject to this anxiety, and it is essential to understand that "the discussion of means and ends is therefore... visible... in disputes over moral limits and competition between research groups all over the world. The setting of the limits

\footnotetext{
18 Heidegger says, "Fear is a fearing in the face of something threatening-of something which is detrimental to Dasein's factical potentiality-for-being, and which brings itself close... within the range of the ready-to-hand and the present-at-hand with which we concern ourselves" [76, p. 391]. The problem here is that fear causes one to forget oneself in the face of that which threatens: "When one has forgotten oneself and makes present a jumble of hovering possibilities, one thus makes possible that bewilderment which goes to make up the mood-character of fear."
} 
depends on a human decision that can always be withdrawn. The limits are not set by the human embryo. Setting limits can therefore only be considered as an act of human responsibility" [14].

One cannot in all due conscience ignore or minimize the fact of danger as irrational fear. Sloterdijk remarks there is ample reason for suspicion: "Due to Hiroshima, humans have reason to believe that the most advanced technologies are uninhibited and reason to distrust the Oppenheimers and Trumans of genetics" [72]. Heidegger was clear that our confrontation with the essence of technology is not a matter of our being either optimistic or pessimistic, just as it is not a matter of our being either "conservative" or "hostile" of scientific research or "liberal" and "enabling" of biotechnology. More accurately, in Heideggerian terms, the limits are disclosed responsibly only in acts of anticipatory resoluteness, and this requires an ethics of care (Sorge) that incorporates practices of leap-ahead solicitude among bioethicists in their relation to stem cell research and genetic engineering. As Sunnie D. Kidd writes, "Heidegger's philosophical ground of self-responsibility of the authentic self is fundamental to the therapeutic process. This movement toward the authentic self, the consciousness of one's own self, one's possibilities, one's finitude, is the ground for the therapeutic encounter. The activation of the projective function of consciousness releases our capacity for imagination" [77]. But the imagination is not free-it is conditioned by human finitude. Only in the appropriation of this comportment will bioethicists hold their authority in guiding biomedical research away from excess and into resolute disclosure of the human future. To do that, both biomedical research scientists and bioethicists must resist all calculative thinking that would determine the human being to be "just one animal among many."

Open Access This article is distributed under the terms of the Creative Commons Attribution Noncommercial License which permits any noncommercial use, distribution, and reproduction in any medium, provided the original author(s) and source are credited.

\section{References}

1. Brassington, Iain. 2007. On Heidegger, medicine, and the modernity of modern medical technology. Medicine, Health Care and Philosophy 10: 185-195.

2. Chan, A.W.S., K.Y. Chong, C. Martinovich, C. Simerly, and G. Schatten. 2001. Transgenic monkeys produced by retroviral gene transfer into mature oocytes. Science 291: 309-312.

3. Graumann, Sigrid. 2000. Experts on philosophical reflection in public discourse-the German Sloterdijk debate as an example. Biomedical Ethics 5 (1). http://www.imew.de/index.php?id=213\& id=213\&type=1. Accessed 12 Aug 2009.

4. Lanza, Robert. 2007. After Dolly: The uses and misuses of human cloning. Journal of Clinical Investigation 117 (2): 282.

5. Little, Melissa, Wayne Hall, and Amy Orlandi. 2006. Delivering on the promise of human stem cell research: What are the real barriers? EMBO Reports 7 (12): 1188-1192.

6. Hyun, Insoo. 2008. Stem cells. In From birth to death and bench to clinic: Bioethics briefing book for journalists, policymakers, and campaigns, ed. Mary Crowley, 159-162. Garrison, NY: The Hastings Center.

7. Moller, Mark S. 2008. Human embryonic stem cell research, justice, and the problem of unequal biological access. Philosophy, Ethics, and Humanities in Medicine. doi:10.1186/1747-5341-3-22. 
8. O'Mathuna, Donal P. 2002. What to call human cloning: The technical terminology increasingly used in the cloning debate sidesteps the ethical questions raised. EMBO Reports 3 (6): 502-505.

9. Patel, P. 2006. A natural stem cell therapy? How novel findings and biotechnology clarify the ethics of stem cell research. Journal of Medical Ethics 32 (4): 235-239.

10. Schulz-Baldes, Annette, Nikola Biller-Andorno, and Alexander Morgan Capron. 2007. International perspectives on the ethics and regulation of human cell and tissue transplantation. Bulletin of the World Health Organization 85 (12): 941-948.

11. Schwedinger, Jamie. 2008. Fundamentals of the stem cell debate. Yale Journal of Biology and Medicine 81 (3): 156-157.

12. Tannert, Christof, Horst-Dietrich Elvers, and Burkhard Jandrig. 2007. The ethics of uncertainty: In the light of possible dangers, research becomes a moral duty. EMBO Reports 8 (10): 892-896.

13. Brock, Dan W. 2006. Is a consensus possible on stem cell research? Moral and political obstacles. Journal of Medical Ethics 32 (1): 36-42.

14. van Leeuwen, Evert. 2004. On the origin, use, and destination of human embryos. European Journal of Endocrinology 151: U13-U16.

15. Hug, Kristina. 2006. Therapeutic perspectives of human embryonic stem cell research versus the moral status of a human embryo-does one have to be compromised for the other? Medicine [Kaunas] 42 (2): 107-114.

16. Parker, Alice. 2009. Scientists create human sperm from stem cells. Time. http://www.time.com/ health/article/0,8599,1909164,00.html. Accessed 09 Aug 2009.

17. Robey, Rebecca. 2009. Sperm from stem cells sparks media furor. BioNews 516. http://www. bionews.org.uk/page_39203.asp. Accessed 10 Aug 2009.

18. Human sperm created from embryonic stem cells. 2009. Cell Medicine. http://www.cellmedicine. com/british-ivd-sperm.asp. Accessed 10 Aug 2009.

19. Guy, Sarah. 2009. Paper announcing creation of sperm retracted for plagiarism. BioNews 519. http://www.bionews.org.uk/page_46041.asp. Accessed 10 Aug 2009.

20. Lensch, William. 2009. Ethical and policy issues at the cutting edge of stem cell science: A summer intensive course. Human/animal chimeras and hybrids-history and scientific utility. June 16. http://academicventures.com/stemcell/presentations.html. Accessed 15 Aug 2009.

21. UKPMC Funders Group. 2005. Being queasy about reconstructing animals. Australian Journal of Professional and Applied Ethics 7 (1): 11-21.

22. Allen, Laura. 2009. First transgenic primate group glows and grows. Popular Science May 28. http:// www.popsci.com/scitech/article/2009-05/first-transgenic-primate-group-glows-and-grows. Accessed 17 Aug 2009.

23. Palmer, Jason. 2009. Glowing monkeys 'to aid research'. BBC News. http://news.bbc.co.uk/go/pr/fr/-/ 2/hi/science/nature/8070252.stm. Accessed 17 Aug 2009.

24. Sasaki, Erika, Hiroshi Suemizu, Akiko Shimada, Kisaburo Hanazawa, Ryo Oiwa, Michiko Kamioka, Ikuo Tomioka, et al. 2009. Generation of transgenic non-human primates with germline transmission. Nature 459: 523-527.

25. Scottish Council on Human Bioethics. 2009. Embryonic, fetal and postnatal animal-human mixtures: An ethical discussion. http://www.schb.org.uk/publications/report\%20-\%20animal-human\%20mix tures.htm. Accessed 17 Aug 2009.

26. Scottish Council on Human Bioethics. 2007. Scottish ethics body extremely concerned about HFEA decision to support animal-human hybrids. http://www.schb.org.uk/publications/press\%2046\%20\%20animal-human\%20combinations\%20-\%202.htm. Accessed 17 Aug 2009.

27. Baylis, Francoise, and Jason Scott Robert. 2006. Primer on ethics and crossing species boundaries. ActionBioscience.org. May. http://www.actionbioscience.org/biotech/baylis_robert.html. Accessed 17 Aug 2009.

28. Ourednik, Václav, Jitka Ourednik, Jonathan D. Flax, W.Michael Zawada, Cynthia Hutt, Chunhua Yang, Kook I. Park, Seung U. Kim, Richard L. Sidman, Curt R. Freed, and Evan Y. Snyder. 2001. Segregation of human neural stem cells in the developing primate forebrain. Science 293: 18201824.

29. GlaxoSmithKline. 2007. The role of transgenic animals in biomedical research. April 24. http:// www.gsk.com/research/about/about_animals_roles.html. Accessed 17 Aug 2009.

30. Hyun, Insoo. 2001. Authentic values and individual autonomy. Journal of Value Inquiry 35 (2): 195-208.

31. Brown, Eric. 2004. The dilemmas of German bioethics. The New Atlantis 5: 37-53. 
32. Kelly, Michael. 2005. Modern science and technology. A review of the proceedings of the 35th annual meeting of The North American Heidegger Society, University of Aberdeen. http://www. abdn.ac.uk/philosophy/endsandmeans/vol5no2/kelly.shtml. Accessed 17 Aug 2009.

33. Rouse, Joseph. 2005. Heidegger on science and naturalism. Wesleyan University Faculty Publications. http://wesscholar.wesleyan.edu/div1facpubs/36. Accessed 17 Aug 2009.

34. Videla, Daniel. n.d. The problem of science in Heidegger's thought. In 20th world congress of philosophy. http://www.bu.edu/wcp/Papers/Scie/ScieVide.htm. Accessed 17 Aug 2009.

35. Matthews, Richard. n.d. The metaphysics of appearance: Heidegger's critique of technology. http://www.mun.ca/phil.codgito/vol2/v2doc3.html. Accessed 17 Aug 2009.

36. Heidegger, Martin. 1972. On time and being (trans: Stambaugh, J.). New York: Harper \& Row.

37. Heidegger, Martin. n.d. Letter on humanism (trans: Miles Groth). http://www.wagner.edu/depart ments/psychology/grothpubs. Accessed 17 Aug 2009.

38. Heidegger, Martin. 1993. Modern science, metaphysics, and mathematics. In Basic writings, ed. D.F. Krell, 247. New York: HarperCollins.

39. Heidegger, Martin. 1962. Being and time. New York: Harper \& Row.

40. Gilliland, Rex. 2002. The destiny of technology: Modern science and human freedom in the later Heidegger. Heidegger Studies 18: 115-128.

41. Heidegger, Martin. 1982. The question concerning technology. New York: Harper.

42. Heidegger, Martin. 1967. What is a thing?. Chicago: Henry Regnery \& Co.

43. Haynes, John. n.d. Calculative thinking and essential thinking in Heidegger's phenomenology. http://www.pdfgeni.com/book/john-haynes-pdf.html. Accessed 17 Aug 2009.

44. Eggan, Kevin. n.d. Kevin Eggan Lab home page. http://golgi.harvard.edu/Eggan/Research/. Accessed 17 Aug 2009.

45. Zwart, Hub A.E. 1994. The moral significance of our biological nature: Methodological consequences of hermeneutical ethics. Ethical Perspectives 1 (1): 71-76. http://www.kuleuven.be/ep/ viewpic.php?LAN=E\&TABLE=EP\&ID=810. Accessed 17 Aug 2009.

46. Lauer, D.W. n.d. Phenomenology and genetic engineering. http://www.heidegger.org.uk/dean lauer.pdf. Accessed 17 Aug 2009.

47. Powell, Alvin. 2008. Stem cell summit hails bench progress, looks to bedside future. Harvard Science. http://www.harvardscience.harvard.edu/foundations/articles/stem-cell-summit-hails-benchprogress-looks-bedside-future. Accessed 17 Aug 2009.

48. Yamanaka, Shimya. 2008. Pluripotency and nuclear reprogramming. Philosophical Transactions of the Royal Society 363: 2079-2087.

49. Kather, Regine. 2006. Continental contributions to philosophy of science. Prolegomena 5 (2): 247-259.

50. Dreyfus, Hubert L. n.d. How Heidegger defends the possibility of a correspondence theory or truth with respect to the entities of natural science. http://socrates.berkeley.edu/ hdreyfus/html/papers. html. Accessed 17 Aug 2009.

51. Anonymous. 2006. Harvard stem cell researchers granted approval: will attempt creation of diseasespecific embryonic stem cell lines. Harvard Gazette. June 2008. http://www.news.harvard.edu/ gazette/2006/06.08/03-stemcell.html. Accessed 30 March 2010.

52. Ashburner, M. 2000. Gene ontology: Tool for the unification of biology. Nature Genetics 25 (1): 25-29.

53. Smith, Barry, Michael Ashburner, Cornelius Rosse, Jonathan Bard, William Bug, Werner Ceusters, Louis J. Goldberg, et al. 2007. The OBO Foundry: Coordinated evolution of ontologies to support biomedical data integration. Nature Biotechnology 25: 1251-1255.

54. Wilburg, Peter. 2003. Heidegger, medicine and 'scientific method': The unheeded heritage of the Zollikon Seminars. New Gnosis Publications.

55. Heidegger, Martin. 2001. Zollikon seminars. Evanston: Northwestern University Press.

56. Heidegger, Martin. 1950. Holzwege. Frankfurt am Main: Klostermann.

57. Westerhoff, Hans V., and Bernard O. Palsson. 2004. The evolution of molecular biology into systems biology. Nature Biotechnology 22: 1249-1252.

58. Mauron, Alex. 2002. Genomic metaphysics. Journal of Molecular Biology 319: 957-962.

59. Saletan, William. 2007. Making manimals. Washington Post June 24. http://www.washingtonpost. com/wp-dyn/content/article/2007/06/22/AR2007062201643.html. Accessed 17 Aug 2009.

60. Babich, Babette. 2007. 'The problem of science' in Nietzsche and Heidegger. Revista Portuguesa de Filosofia 63: 205-237. http://fordham.bepress.com/cgi/viewcontent.cgi?article=1006\&context=phil_ research. Accessed 17 Aug 2009. 
61. Schildrick, Margrit. 2005. Beyond the body of bioethics: Challenging conventions. In Ethics of the body, ed. Margrit Schildrick and R. Mykitiuk, 1-28. Cambridge: MIT Press.

62. Rorty, Mary V. n.d. For the love of the game: Peter Sloterdijk and public controversies in bioethics. http://www.stanford.edu/ mvr2j/for_love.html. Accessed 05 Aug 2009.

63. Demick, Barbara, and Karen Kaplan. 2005. Panel finds against South Korean scientists. Global Technology Forum. December 28. http://globaltechforum.eiu.com/index.asp?layout+rich_story\&doc_ id $+7936 \&$ title $=$ Panel + finds + against + South + Korean + scientist\&categoryid=7\&channelid=3. Accessed 09 Aug 2009.

64. Resnik, David B., Adil Shamoo, and Sheldon Krimsky. 2006. Fraudulent human embryonic stem cell research in South Korea: Lessons learned. Accountability in Research 13 (1): 101-109.

65. Rossner, Mike. 2007. Hwang case review committee misses the mark. Journal of Cell Biology 176 (2): 131-132.

66. Secker, Barbara. 1999. The appearance of Kant's deontology in contemporary Kantianism: Concepts of patient autonomy in bioethics. Journal of Medicine and Philosophy 24 (1): 43-66.

67. Welie, Jos V.M. 1994. Authenticity as a foundational principle of medical ethics. Theoretical Medicine 15 (3): 211-225.

68. Heine, Steven. 1985. Existential and ontological dimensions of time in Heidegger and Dogen. Albany: SUNY Press.

69. Svenaeus, Fredrik. 2007. A Heideggerian defense of therapeutic cloning. Theoretical Medicine and Bioethics 28 (1): 31-62.

70. Mauron, Alex. 2003. Renovating the house of being: Genomes, souls, and selves. Annals of the New York Academy of Sciences 1001: 240-252.

71. Kurz, Paul. 2004. Can the sciences help us to make wise ethical judgments? Skeptical Inquirer 28 (5). http://www.csicop.org/si/show/can_the_sciences_help_us_to_make_wise_ethical_judgments. Accessed 09 Aug 2009.

72. Sloterdijk, Peter. n.d. The operable man: On the ethical state of gene technology. Goethe Institute. http://www.petersloterdijk.net/international/texts/en_texts/en_texts_PS_operable_man.html. Accessed 06 Aug 2009.

73. Lewis, Michael. 2005. Heidegger and the place of ethics. New York: Continuum International Publishing Group.

74. Sloterdijk, Peter. 1998-2004. Sphären, 3 vols. Berlin: Suhrkamp Verlag.

75. Sabatino, Charles J. 2007. A Heideggerian reflection on the prospects of technology. Janus Head 10 (1): $63-76$.

76. Gagnon, Louise. 2002. Stem cell research: 'With no law, the situation is very permissive'. Canadian Medical Association Journal 166 (8): 1077.

77. Kidd, Sunnie D. n.d. The power of imagination. Inbetweenness. http://www.inbetweenness.com/ Sunnie's\%20Publications/THE\%20POWER\%20OF\%20IMAGINATION.pdf. Accessed 09 Aug 2009. 